Article

\title{
CpG Site-Specific Regulation of Metallothionein-1 Gene Expression
}

\author{
Shoko Ogushi ${ }^{1, \dagger}$, Yuya Yoshida ${ }^{2}$, Tsuyoshi Nakanishi ${ }^{3}$ (D) and Tomoki Kimura ${ }^{1, *(D)}$ \\ 1 Department of Life Science, Faculty of Science and Engineering, Setsunan University, \\ Neyagawa 572-8508, Japan; ogushi.shouko@ma.medience.co.jp \\ 2 Department of Pathological Biochemistry, Faculty of Pharmaceutical Sciences, Setsunan University, \\ Hirakata 573-0101, Japan; yoshida@pharm.setsunan.ac.jp \\ 3 Laboratory of Hygienic Chemistry and Molecular Toxicology, Gifu Pharmaceutical University, \\ Gifu 501-1196, Japan; nakanishi@gifu-pu.ac.jp \\ * Correspondence: tomoki@lif.setsunan.ac.jp; Tel.: +81-72-839-8084 \\ † Present address: Kashima Laboratory, LSI Medience Corporation, Kamisu 314-0255, Japan.
}

Received: 18 July 2020; Accepted: 15 August 2020; Published: 19 August 2020

\begin{abstract}
Metal-binding inducible proteins called metallothioneins (MTs) protect cells from heavy-metal toxicity. Their transcription is regulated by metal response element (MRE)-binding transcription factor-1 (MTF1), which is strongly recruited to MREs in the MT promoters, in response to $\mathrm{Zn}$ and $\mathrm{Cd}$. Mouse Mt1 gene promoter contains 5 MREs (a-e), and MTF1 has the highest affinity to MREd. Epigenetic changes like DNA methylation might affect transcription and, therefore, the cytoprotective function of MT genes. To reveal the CpG site(s) critical for Mt1 transcription, we analyzed the methylation status of $\mathrm{CpG}$ dinucleotides in the $\mathrm{Mt1}$ gene promoter through bisulfite sequencing in P1798 mouse lymphosarcoma cells, with high or low MT expression. We found demethylated CpG sites near MREd and MREe, in cells with high expression. Next, we compared $M t 1$ gene-promoter-driven Lucia luciferase gene expression in unmethylated and methylated reporter vectors. To clarify the effect of complete and partial CpG methylation, we used M.SssI (CG $\left.\rightarrow{ }^{5 \mathrm{~m}} \mathrm{CG}\right)$ and HhaI (GCGC $\rightarrow \mathrm{G}^{5 \mathrm{~m}} \mathrm{CGC}$ )-methylated reporter vectors. Point mutation analysis revealed that methylation of a CpG site near MREd and MREe strongly inhibited Mt1 gene expression. Our results suggest that the methylation status of this site is important for the regulation of $M t 1$ gene expression.
\end{abstract}

Keywords: metallothionein; epigenetics; heavy-metal toxicity

\section{Introduction}

Metallothioneins (MTs) are low-molecular-weight, cysteine-rich, metal-binding proteins [1]. In mammals, there are four main isoforms, MT1 to MT4. The expression of ubiquitous MT1 and MT2 isoforms is induced by heavy metals. These isoforms protect against toxic heavy metals by sequestering them and lowering their concentrations at critical intracellular sites [2-4]; they also provide protection against reactive oxygen species (ROS) [5-7]. The roles of MT1/2 in immunity and obesity were reported using MT1/2 knock-out mice [8], and changes in the MT expression levels might affect the biological functions of MTs.

Epigenetics refers to the control of gene expression via mechanisms not directly related to the DNA coding sequence [9]. Epigenetic modifications regulate gene expression through various epigenomic marks; for example, methylation of cytosine residues at CpG sites with histone modifications, to regulate gene expression $[10,11]$. The methylated CpG sites recruit methyl CpG-binding domain proteins and thereby prevent the binding of transcription factors to the DNA [12]. CpG methylation or demethylation in the MT promoters might cause individual differences in MT expression levels, and therefore differences in susceptibility to heavy metal toxicity. 
Metal response element (MRE)-binding transcription factor-1 (MTF1) activates MT1/2 transcription in response to heavy metals [13]. Among 5 MREs (a-e) in the $5^{\prime}$-flanking region of the mouse $M t 1$ gene, MTF1 shows the highest affinity to MREd [14,15]. MTF1 is an essential transcription factor for basal and metal-induced MT expression [16]. A transcriptional/epigenetic regulator p300, histone acetyltransferase (HAT), is required for MT induction in response to metals [17]. The importance of the formation of the complex containing p300 was shown, such that hexavalent chromium $\left(\mathrm{Cr}^{6+}\right)$ inhibited MT induction via inhibition of this complex formation $[18,19]$. However, the inhibitory effects of $\mathrm{Cr}^{6+}$ on MT induction were due to its effects on the HAT-independent transactivation ability of p300. The importance of p300 histone acetyltransferase activity in MT expression remains unclear. MT expression is modulated by epigenetic modifications [20-24]. Zinc deficiency enhances the cadmium-induced expression of mouse hepatic MT2, without change of basal MT2 expression in vivo; it leads to hypermethylation of $\mathrm{CpG}$ sites and enrichment in the acetylation of histones $\mathrm{H} 3 / \mathrm{H} 4$ in the 5'-flanking region of the $M t 2$ gene [25]. We reported that the $M t 1$ gene is suppressed in P1798 mouse lymphosarcoma cells, but long-term cadmium $(\mathrm{Cd})$ exposure $(0.1 \mu \mathrm{M}, 7 \mathrm{days})$ and subsequent short-term exposure to high Cd concentrations $(10 \mu \mathrm{M}, 3 \mathrm{hr})$ decreases MT1 DNA methylation and induces the Mt1 gene [26]. We hypothesized that certain CpG sites in the MT1 promoter were crucial for $\mathrm{Mt1}$ gene expression, because the $\mathrm{CpG}$ sites were reported to be crucial for the regulation of several genes $[27,28]$. However, the CpG site(s) whose methylation status is important for MT1 expression is not yet determined.

Here, we found that the methylation status of CpG dinucleotides in the $5^{\prime}$-flanking region of the Mt1 gene differed in P1798 cells expressing high and low levels of MT1. Luciferase analysis revealed that the effect of $\mathrm{CpG}$ methylation was not uniform. We found that methylation status of a CpG site near MREd and MREe is important for the regulation of $M t 1$ gene expression.

\section{Results and Discussion}

\subsection{Characterization of P1798 Cells Treated with 5-AzaC Plus Cd}

In P1798 cells, MT1 expression is extremely low but is increased by 5-azacytidine (5-AzaC) plus $\mathrm{Cd}(5-\mathrm{AzaC} / \mathrm{Cd})$ treatment, because of CpG demethylation by 5-AzaC and MTF1 activation by Cd [22]. The level of MT1 mRNA was increased in 5-AzaC/Cd-treated cells (Table 1). Untreated P1798 cells showed extremely low MT1 expression-98.9\% cells had MT1 expression (arbitrary units) under $3 \times 10^{2}$ (Figure 1A, left panel). After 5-AzaC/Cd treatment, 51.5\% of the cells still had low MT1 expression and $48.5 \%$ of the cells had high MT1 expression (over $3 \times 10^{2}$ on the MT1 axis). Bisulfite sequencing revealed that cytosines at CPG sites in some regions of the MT1 promoter tended to be methylated in cells with low levels of MT1 expression but unmethylated in cells with high levels. The first CpG site and the 14th to 21st CpG sites (between -215 to $-127 \mathrm{bp}$ ) from the transcription start site were unmethylated in all cells with high MT1 expression (Figure 1B). Similar ununiformed demethylation after 5-AzaC treatment in P1798 cells was reported by Ghoshal et al. [22]. They analyzed methylation status on the 1st to 18th CpG sites and reported that 5-AzaC treatment for $120 \mathrm{hr}$ showed complete demethylation in the region. Thirty-six hour treatment showed partial demethylation only in 1st, 3rd-5th, 7th, and 13th-18th CpG sites. The latter region was near MREd and MREe. As MREd is the most active element in the response to $\mathrm{Zn}[14,15]$, we hypothesized that the demethylation of these CpG sites are integrally involved in the expression of MT1.

Table 1. Relative metallothionein-1 (MT1) and $\beta$-actin mRNA levels after 5-AzaC and Cd treatment.

\begin{tabular}{cccc}
\hline Gene & Control & Cd & 5-AzaC + Cd \\
\hline MT1 & $1.0 \pm 1.9$ & $0.9 \pm 0.7$ & $31,214.4 \pm 16,310.7^{*}$ \\
$\beta$-actin & $1.0 \pm 0.6$ & $0.9 \pm 0.3$ & $0.9 \pm 0.5$
\end{tabular}

Expression levels were normalized using $18 \mathrm{~S}$ rRNA. Values are expressed as the means \pm SD from $3-4$ independent experiments. ${ }^{*} p<0.01$ versus the control group. 

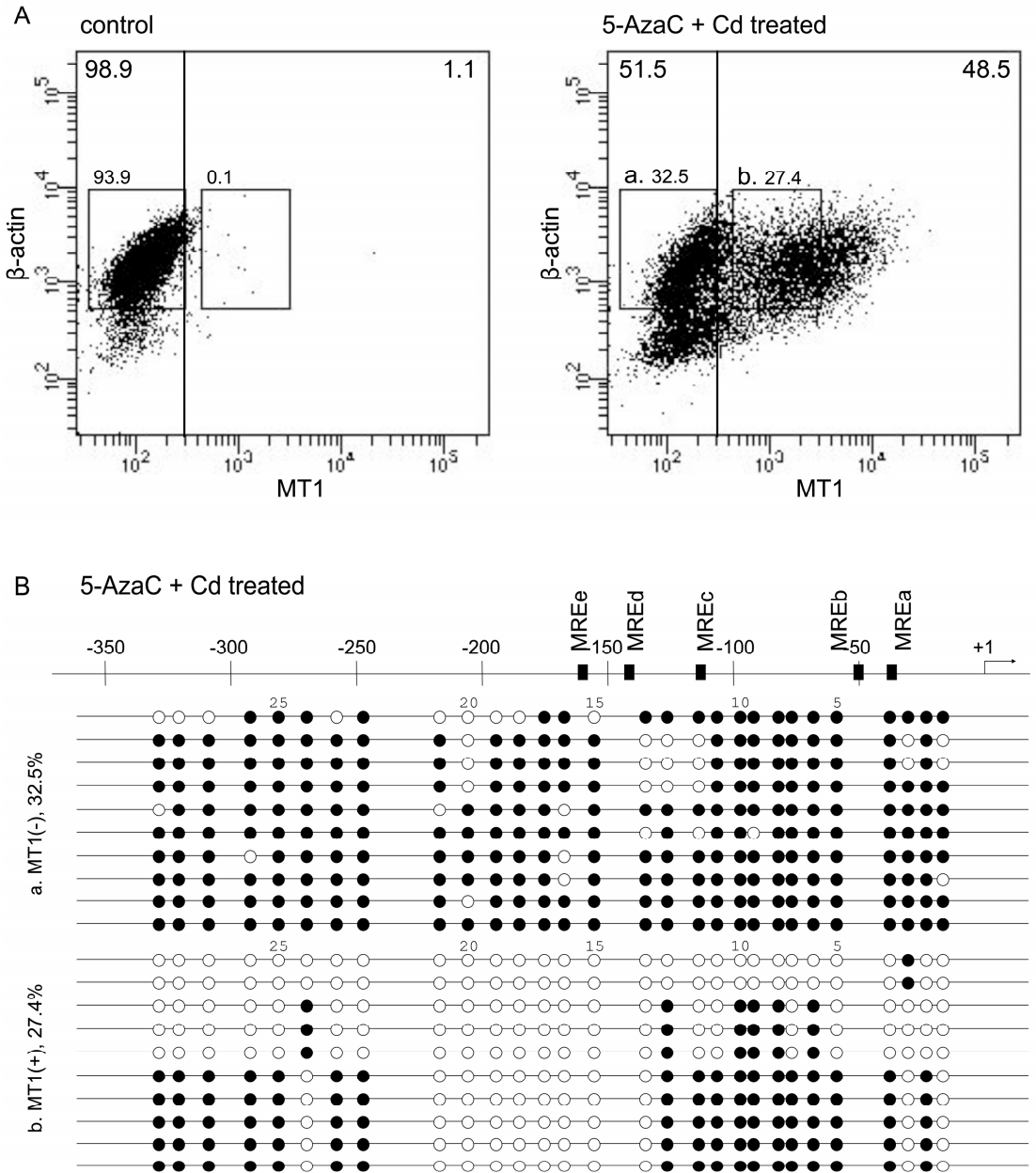

Figure 1. PrimeFlow RNA assay of 5-AzaC and Cd-treated P1798 cells and bisulfite sequencing. (A) P1798 cells were treated with vehicle (control) or 5-AzaC $(2.5 \mu \mathrm{M}, 2$ days) and Cd $(10 \mu \mathrm{M}$, $3 \mathrm{~h}$ ). Experiments were reproduced three times with similar results. Results from a representative experiment are shown. (B) Results of bisulfite sequencing of (a) and (b) cell fractions. Designations of CpG dinucleotides are represented by circles: closed-methylated; open-unmethylated. Each row represents data from a single cell.

\subsection{Effect of CpG Methylation in the 5'-Flanking Region of the MT1 Gene on Lucia Luciferase Reporter} Gene Expression

Next, we compared the Mt1 gene promoter-driven Lucia luciferase gene expression in unmethylated and methylated reporter vectors in mouse embryonic fibroblasts (MEFs) (Figure 2). CpG methylation by M.SssI inhibited MT1 promoter-mediated expression of Lucia luciferase by $89 \%$ vs. the unmethylated group (Figure 3A). Non-uniform regulatory effects of the methylation status of $\mathrm{CpG}$ sites were reported $[27,28]$. Methylation of some CpG sites remarkably down-regulated gene expression, whereas methylation of other CpG sites had no effect in the NOS2 and MMP9 gene. Our report showed that Cd increased MT inducibility with demethylation of the -200 to $-55 \mathrm{bp}$ region of the MT1 promoter [26]. However, we did not identify specific CpG sites involved in MT1 expression. To clarify which CpG site is important, we used reporter vectors with deletions or point mutations. In pCpGf- $\triangle$ MREde, the inhibitory effect of M.SssI was not observed, but $28 \%$ of inhibition remained in pCpGf- $\triangle$ MREabc (Figure $3 \mathrm{~A}$ ). Similar results were observed in mutated reporter vectors. The inhibitory effect of M.SssI was not significant in pCpGf-m14-21 (CpG sites near MREd and e mutated; $26 \%$ inhibition), but was significant in pCpGf-m1-12 (CpG sites near MREa, b, and c mutated; $42 \%$ inhibition; Figure $3 B$ ). 


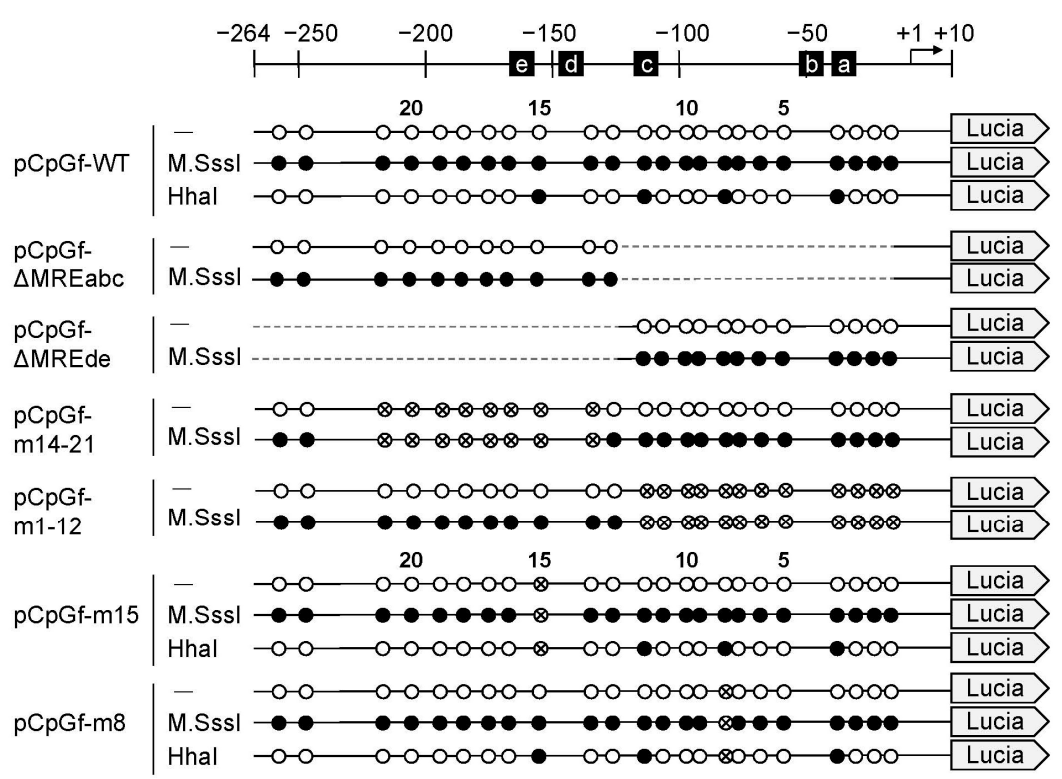

Figure 2. Structure of the MT1 promoter region and the introduced deletions and point mutations. Schematic at the top shows the transcription start site (arrow) and metal response element (MREs). CpG dinucleotides are as in Figure 1; crossed, mutated. Lucia, Lucia luciferase gene.

A

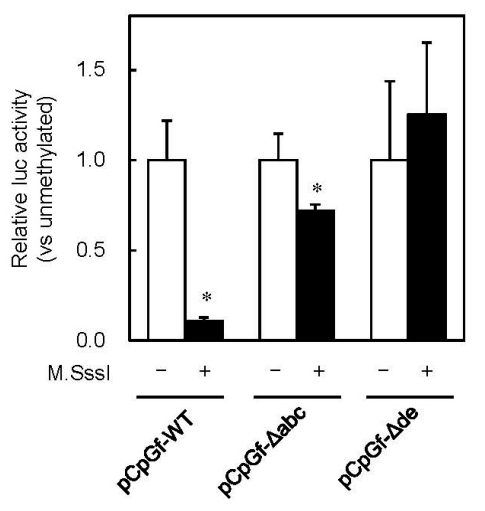

B

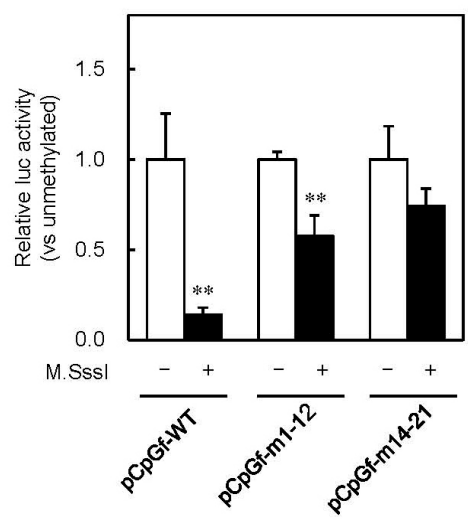

Figure 3. Effect of CpG methylation in MT1 promoter on Lucia luciferase activity. Mouse embryonic fibroblasts (MEFs) were transfected with unmethylated or M.SssI-methylated Lucia reporter vectors carrying (A) deletions or (B) point mutations. Luciferase reporter vector (pGL4.12-SV40) was co-transfected for normalization of transfection efficiency. Reporter gene expression was measured using the Dual-Luciferase Reporter Assay System, and Lucia (luc) activity was normalized to firefly luciferase activity. Values are expressed as the means \pm SD from three independent experiments. ${ }^{*} p<0.05,{ }^{* *} p<0.01$ versus the unmethylated vector group.

To clarify the effect of partial CpG methylation on MT1 promoter activity, we methylated the reporter vectors with HhaI methyltransferase (Figure 2). M.SssI inhibited the promoter activity by $88 \%$ and HhaI inhibited it by $69 \%$. Similar inhibitory effects were observed in cells treated with $200 \mu \mathrm{M} Z \mathrm{Zn}$ or $10 \mu \mathrm{M}$ Cd. The inhibitory effect of M.SssI was still observed with pCpGf-m15 (Figure 4C). In pCpGf-m8, the inhibitory effect of M.SssI was not significant in the Cd-treated group, but its inhibitory tendency was observed (Figure 4B). The non-uniform effect of CpG methylation was much clearer with HhaI. The inhibitory effect of HhaI on pCpGf-WT and pCpGf-m8 vectors was similar to that of M.SssI in the untreated and Zn-treated groups (Figure 4B), but not on pCpGf-m15 (Figure 4C). The inhibitory effect of HhaI on pCpGf-m15 was not observed in the untreated and Cd-treated groups (Figure 4C). These results suggest that the 15th CpG site (located between MREd and MREe) greatly affected MT1 
expression. This location, CpG15, did not exactly match the specific demethylation site in our previous work in long-term Cd-treated P1798 cells [26]. Methylation/demethylation near CpG15, not CpG15, might be important for MT1 expression. Site-specific methylation/demethylation techniques [29,30] are needed to answer this question.

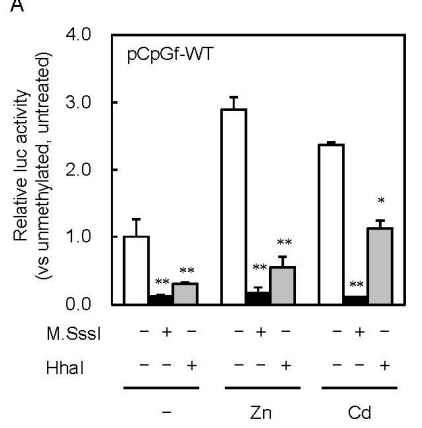

B

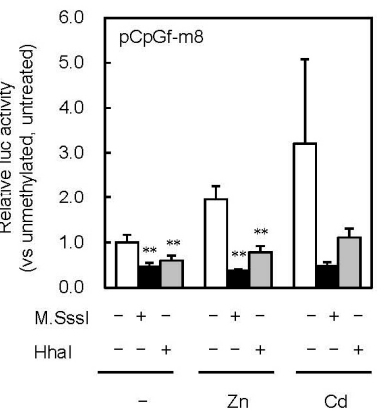

C

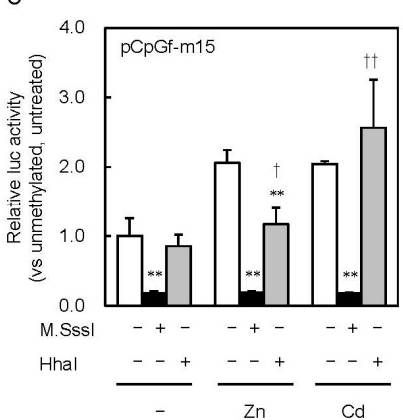

Figure 4. Effect of partial CpG methylation in the MT1 promoter on Zn- and Cd-induced Lucia luciferase activity. MEFs were transfected with unmethylated or M.SssI- or HhaI methyltransferase-methylated Lucia reporter vectors carrying wild-type (A), point mutations of CpG8 (B) and CpG15 (C). Reporter gene expression was measured $6 \mathrm{~h}$ after $\mathrm{Zn}$ or $\mathrm{Cd}$ addition. Values are expressed as the means $\pm \mathrm{SD}$ from three independent experiments. ${ }^{*} p<0.05,{ }^{* *} p<0.01$ versus the unmethylated group. ${ }^{\dagger} p<0.05$, ${ }^{++} p<0.01$ versus the M.SssI-methylated group.

\subsection{Involvement of the MTF1-MRE Pathway on the Inhibition of MT1 Expression by CpG Methylation}

MREd is the most active element in response to Zn [14,15]. MT1 promoter activity might be inhibited by HhaI methyltransferase, through inhibition of the MTF1-MRE pathway. We investigated whether this pathway was involved in the inhibition caused by CpG methylation. Basal MT expression was low in MTF1-knockout (MTF1-KO) cells, and Zn or Cd treatments did not increase it [16]. In MTF1-KO cells, the Zn and Cd treatments did not increase MT1 promoter-driven Lucia luciferase activity (Figure 5A). CpG methylation by M.SssI inhibited the activity, whereas methylation by HhaI did not (Figure 5B). Complete CpG methylation by M.SssI might inhibit recruitment of basic transcription apparatus or change the chromatin structure.

A

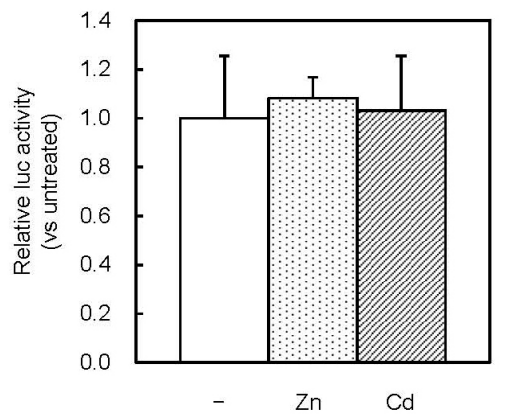

B

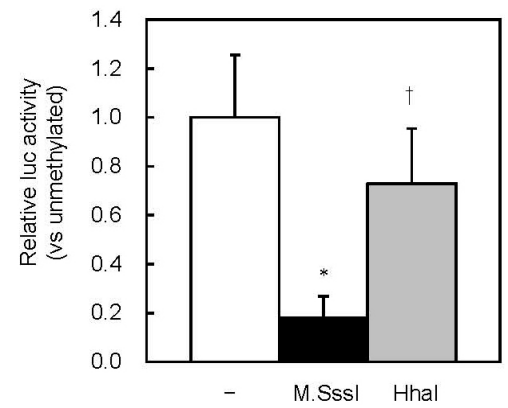

Figure 5. Effect of CpG methylation on MT1 promoter activity in MTF1 KO cells. (A) Cells were transfected with unmethylated Lucia reporter vectors. Reporter gene expression was measured $6 \mathrm{~h}$ after $\mathrm{Zn}$ or $\mathrm{Cd}$ addition. Values for neither treatment group were significantly different from the untreated group. (B) MTF1-KO cells were transfected with unmethylated or M.SssI- or HhaI methyltransferase-methylated Lucia reporter vectors. Values are expressed as the means \pm SD from three independent experiments. ${ }^{*} p<0.01$ versus the unmethylated group. ${ }^{+} p<0.01$ versus the M.SssI-methylated group. 


\section{Materials and Methods}

\subsection{Cell Culture and Treatment}

P1798 mouse lymphosarcoma cells-a gift from Dr. A.E. Thompson, University of Texas (Galveston, TX, USA)—were cultured as in [26]. P1798 cells were seeded at a density of $2.5 \times 10^{5}$ cells/mL every 2 days. P1798 cells were treated with 5-AzaC (2.5 $\mu \mathrm{M}, 2$ days) and subsequent exposure to Cd (10 $\mu \mathrm{M}$, $3 \mathrm{~h}$ ). MEFs and MTF1-KO MEFs were provided by Dr. G.K. Andrews, University of Kansas Medical Center (Kansas City, KS, USA); these were cultured as in [17]. MEFs were seeded at a density of $4.0 \times 10^{4}$ cells/well of 24 well plate. Cell viability was measured with trypan blue exclusion assays [31]. Before the transfection for the luciferase reporter assay, the cells were cultured for $24 \mathrm{~h}$.

\subsection{Quantitative Reverse Transcription PCR}

RNA was isolated from cells by using Isogen RNA extraction reagent (Nippon Gene, Tokyo, Japan), in accordance with the manufacturer's protocol. Extracted total RNA was converted to the complementary DNA, by using a High Capacity cDNA Reverse Transcription Kit (Thermo Fisher Scientific, Waltham, MA, USA) and a random primer. For quantitative PCR (qPCR), we used Premix Ex Taq (Probe qPCR) (Takara Bio, Kusatsu, Japan) or TB Green Premix Ex Taq (Tli RNaseH Plus) (Takara Bio) as the qPCR reagent and an Eco Real-Time PCR System (Illumina, San Diego, CA, USA). For measurement of MT1 cDNA, we used TaqMan probes (for MT1: Mm00496660_g1; for 18S rRNA: 4319413E; Applied Biosystems, Carlsbad, CA, USA). Gene-specific primers for $\beta$-actin was as follows-forward (F) primer, 5'-GAAATCGTGCGTGACATCAAAG-3'; reverse (R) primer, 5'-TGTAGTTTCATGGATGCCACA G-3'.

\subsection{PrimeFlow RNA Assay}

Probes and reagents were part of the PrimeFlow RNA Assay Kit (eBioscience, San Diego, CA, USA) [32]. P1798 cells $\left(5.0 \times 10^{6}\right)$ were incubated with permeabilization buffer containing RNase inhibitors, fixed and hybridized with target gene-specific probes. Cells were stained with PreAmp Mix, Amp Mix, and probes labeled with Alexa Fluor 647 (Type 1) for MT1 and Alexa Fluor 488 (Type 4) for $\beta$-actin, according to the manufacturer's protocol. Flow cytometric analysis was performed using a BD FACSAria Fusion cell sorter (BD Biosciences, San Jose, CA, USA). Cells were sorted and collected according to the MT1 expression level.

\subsection{Bisulfite Genomic Sequencing Assay}

Bisulfite conversion reactions, PCR amplification, cloning of the PCR product and sequencing were performed as in [26]. The sequences of the sense and antisense primers were as follows: $F$ primer, 5'-TTAGGAATTTTAGGAAAGGAGA-3'; R primer, 5'-TAAAAAACAACCTACCCTCTTT-3'. The QUMA program (http://quma.cdb.riken.jp/) was used to align, visualize, and quantify sequence data for CpG methylation analysis [33].

\subsection{Luciferase Reporter Assay}

Lucia reporter plasmid pCpGfree-basic-Lucia was purchased from InvivoGen (San Diego, CA, USA); the plasmid had no promoter and was devoid of $\mathrm{CpG}$ dinucleotides. The reporter vector pCpGfree-MT-264/+10 was constructed as in [18]; the vector contained the mouse MT1 promoter (bases -264 to +10 relative to the transcription start site). Point mutants and deletion mutants were constructed by inverse PCR using the PrimeSTAR Mutagenesis Basal Kit (Takara Bio) or by cloning at HindIII/NcoI sites, with synthetic double-stranded DNA fragments (Integrated DNA Technologies, Coralville, IA, USA) (Supplementary Table S1). Firefly luciferase reporter control plasmid pGL4.12-SV40 was constructed using pGL4.12 [luc2CP] (Promega, Madison, WI, USA), SV40 enhancer, and the early promoter fragment obtained from pRL-SV40 (Promega) and In-Fusion Cloning Kit (Takara Bio). Lucia reporter vectors were methylated with $\mathrm{CpG}$ methyltransferase (M.SssI; CG $\rightarrow{ }^{5 \mathrm{~m}} \mathrm{CG}$; New England 
Biolabs, Ipswich, MA, USA) or HhaI methyltransferase (GCGC $\rightarrow G^{5 m} C G C$; New England Biolabs) for $1 \mathrm{~h}$ at $37^{\circ} \mathrm{C}$ (Figure 2). Methylated reporter vectors were purified through extraction with NucleoSpin Gel and PCR Clean-up (TaKaRa Bio). Methylation completeness was confirmed using the methylation-sensitive HhaI restriction enzyme.

Transfection was performed with transfection reagent FuGENE HD (Promega, Madison, WI, USA), according to the manufacturer's protocol. In brief, the reporter vector, pGL4.12-SV40 and pEGFP were mixed at a 1:0.005:1 ratio in Opti-MEM medium (Invitrogen, Carlsbad, CA, USA). The plasmid mixture $(0.3 \mu \mathrm{g}$ per well) was mixed with FuGENE HD ( $2.0 \mu \mathrm{L}$ per well), incubated for 15 min at room temperature, added to the cells cultured in a 24-well plate, and cultured for $24 \mathrm{~h}$. The cells were lysed in $1 \times$ passive lysis buffer (Promega), and luciferase activity was measured using the Dual-Luciferase Reporter Assay System (Promega) and GloMax 20/20n luminometer (Promega).

\subsection{Statistical Analysis}

Data were analyzed with Tukey's test in PASW Statistics 18 software (IBM, Armonk, NY, US). Differences between groups were considered significant at $p<0.05$.

\section{Conclusions}

In the present study, we found that methylation/demethylation of the CpG sites near MREd and MREe is important for regulation of $M t 1$ gene expression. Our findings suggest that $M t 1$ gene expression is fine-tuned through epigenetic regulation. To understand the exact regulation mechanisms of $M t 1$ gene expression, it is necessary to clarify which $\mathrm{CpG}$ sites or which $\mathrm{CpG}$ regions are important, more definitely. Site-specific methylation/demethylation techniques $[29,30]$ are needed to clarify the important sites and regions. On the other hand, our finding was from the experiments using exogenous $M t 1$ gene promoter-driven Lucia luciferase reporter vectors. It is important to clarify whether ununiformed methylation/demethylation of the CpG sites also regulates endogenous $M t 1$ gene expression and what environmental factors influence $\mathrm{CpG}$ methylation and modify Mt1 gene expression. As MT1 plays a central role in defense against heavy metals and ROS, the fine-tuned Mt1 gene expression might affect many biological functions. Further investigation is needed to explore the biological role of the non-uniform role of specific CpG sites in the regulation of MT1 expression.

Supplementary Materials: The following is available online at http://www.mdpi.com/1422-0067/21/17/5946/s1, Table S1: Primer and synthetic DNA sequences for construction of reporter vectors.

Author Contributions: Conceptualization, T.K.; methodology, S.O. and T.K.; formal analysis, S.O. and T.K.; investigation, S.O., Y.Y., T.N., and T.K.; resources, Y.Y., T.N. and T.K.; data curation, S.O., Y.Y., and T.K.; writing-original draft preparation, S.O.; writing-review and editing, T.N. and T.K.; supervision, T.K.; project administration, T.K.; funding acquisition, T.K. All authors have read and agreed to the published version of the manuscript.

Funding: This work was partially supported by JSPS KAKENHI grant number JP25460179 (to Tomoki Kimura).

Acknowledgments: We thank Syoko Miyamoto (Setsunan University) for the excellent technical assistance.

Conflicts of Interest: The authors declare no conflict of interest.

\section{Abbreviations}

$\begin{array}{ll}\text { MT } & \text { Metallothionein } \\ \text { ROS } & \text { Reactive oxygen species } \\ \text { MRE } & \text { Metal response element } \\ \text { MTF1 } & \text { MRE-binding transcription factor-1 } \\ \text { HAT } & \text { histone acetyltransferase } \\ \text { 5-AzaC } & \text { 5-azacytidine } \\ \text { MEF } & \text { Mouse embryonic fibroblast } \\ \text { MTF1-KO } & \text { MTF1-knockout } \\ \text { qPCR } & \text { quantitative PCR }\end{array}$




\section{References}

1. Coyle, P.; Philcox, J.C.; Carey, L.C.; Rofe, A.M. Metallothionein: The multipurpose protein. Cell. Mol. Life Sci. 2002, 59, 627-647. [CrossRef]

2. Michalska, A.E.; Choo, K.H. Targeting and germ-line transmission of a null mutation at the metallothionein I and II loci in mouse. Proc. Natl. Acad. Sci. USA 1993, 90, 8088-8092. [CrossRef] [PubMed]

3. Masters, B.A.; Kelly, E.J.; Quaife, C.J.; Brinster, R.L.; Palmiter, R.D. Targeted disruption of metallothionein I and II genes increases sensitivity to cadmium. Proc. Natl. Acad. Sci. USA 1994, 91, 584-588. [CrossRef] [PubMed]

4. Klaassen, C.D.; Liu, J.; Diwan, B.A. Metallothionein protection of cadmium toxicity. Toxicol. Appl. Pharmacol. 2009, 238, 215-220. [CrossRef] [PubMed]

5. Thornalley, P.J.; Vašák, M. Possible role for metallothionein in protection against radiation-induced oxidative stress. Kinetics and mechanism of its reaction with superoxide and hydroxyl radicals. Biochim. Biophys. Acta (BBA) Protein Struct. Mol. 1985, 827, 36-44. [CrossRef]

6. Chiaverini, N.; De Ley, M. Protective effect of metallothionein on oxidative stress-induced DNA damage. Free Radic. Res. 2010, 44, 605-613. [CrossRef]

7. Ling, X.-B.; Wei, H.-W.; Wang, J.; Kong, Y.-Q.; Wu, Y.-Y.; Guo, J.-L.; Li, T.-F.; Li, J.-K. Mammalian Metallothionein-2A and Oxidative Stress. Int. J. Mol. Sci. 2016, 17, 1483. [CrossRef]

8. Kimura, T.; Kambe, T. The Functions of Metallothionein and ZIP and ZnT Transporters: An Overview and Perspective. Int. J. Mol. Sci. 2016, 17, 336. [CrossRef]

9. Bird, A. Perceptions of epigenetics. Nature 2007, 447, 396-398. [CrossRef]

10. Bird, A. DNA methylation patterns and epigenetic memory. Genes Dev. 2002, 16, 6-21. [CrossRef]

11. Henikoff, S.; Greally, J.M. Epigenetics, cellular memory and gene regulation. Curr. Biol. 2016. [CrossRef] [PubMed]

12. Du, Q.; Luu, P.-L.; Stirzaker, C.; Clark, S.J. Methyl-CpG-binding domain proteins: Readers of the epigenome. Epigenomics 2015, 7, 1051-1073. [CrossRef] [PubMed]

13. Kimura, T.; Itoh, N.; Andrews, G.K. Mechanisms of Heavy Metal Sensing by Metal Response Element-binding Transcription Factor-1. J. Health Sci. 2009, 55, 484-494. [CrossRef]

14. Searle, P.F.; Stuart, G.W.; Palmiter, R.D. Building a metal-responsive promoter with synthetic regulatory elements. Mol. Cell. Biol. 1985, 5, 1480-1489. [CrossRef] [PubMed]

15. Labbé, S.; Prévost, J.; Remondelli, P.; Leone, A.; Séguin, C. A nuclear factor binds to the metal regulatory elements of the mouse gene encoding metallothionein-I. Nucleic Acids Res. 1991, 19, 4225-4231. [CrossRef] [PubMed]

16. Heuchel, R.; Radtke, F.; Georgiev, O.; Stark, G.; Aguet, M.; Schaffner, W. The transcription factor MTF-1 is essential for basal and heavy metal-induced metallothionein gene expression. EMBO J. 1994, 13, 2870-2875. [CrossRef]

17. Li, Y.; Andrews, G.K.; Laity, J.H.; Kimura, T.; Huyck, R.W. Zinc-Induced Formation of a Coactivator Complex Containing the Zinc-Sensing Transcription Factor MTF-1, p300/CBP, and Sp1. Mol. Cell. Biol. 2008, 28, 4275-4284. [CrossRef]

18. Kimura, T.; Li, Y.; Okumura, F.; Itoh, N.; Nakanishi, T.; Sone, T.; Isobe, M.; Andrews, G.K. Chromium (VI) inhibits mouse metallothionein-I gene transcription by preventing the zinc-dependent formation of an MTF-1-p300 complex. Biochem. J. 2008, 415, 477-482. [CrossRef]

19. Kimura, T.; Okumura, F.; Onodera, A.; Nakanishi, T.; Itoh, N.; Isobe, M. Chromium (VI) inhibits mouse metallothionein-I gene transcription by modifying the transcription potential of the co-activator p300. J. Toxicol. Sci. 2011, 36, 173-180. [CrossRef]

20. Majumder, S.; Ghoshal, K.; Li, Z.; Bo, Y.; Jacob, S.T. Silencing of metallothionein-I gene in mouse lymphosarcoma cells by methylation. Oncogene 1999, 18, 6287-6295. [CrossRef]

21. Ghoshal, K.; Majumder, S.; Li, Z.; Dong, X.; Jacob, S.T. Suppression of Metallothionein Gene Expression in a Rat Hepatoma Because of Promoter-specific DNA Methylation. J. Biol. Chem. 2000, 275, 539-547. [CrossRef] [PubMed] 
22. Ghoshal, K.; Datta, J.; Majumder, S.; Bai, S.; Dong, X.; Parthun, M.; Jacob, S.T. Inhibitors of Histone Deacetylase and DNA Methyltransferase Synergistically Activate the Methylated Metallothionein I Promoter by Activating the Transcription Factor MTF-1 and Forming an Open Chromatin Structure. Mol. Cell. Biol. 2002, 22, 8302-8319. [CrossRef] [PubMed]

23. Majumder, S.; Kutay, H.; Datta, J.; Summers, D.; Jacob, S.T.; Ghoshal, K. Epigenetic regulation of metallothionein-I gene expression: Differential regulation of methylated and unmethylated promoters by DNA methyltransferases and methyl CpG binding proteins. J. Cell. Biochem. 2006, 97, 1300-1316. [CrossRef] [PubMed]

24. Okumura, F.; Li, Y.; Itoh, N.; Nakanishi, T.; Isobe, M.; Andrews, G.K.; Kimura, T. The zinc-sensing transcription factor MTF-1 mediates zinc-induced epigenetic changes in chromatin of the mouse metallothionein-I promoter. Biochim. Biophys. Acta 2011, 1809, 56-62. [CrossRef]

25. Kurita, H.; Ohsako, S.; Hashimoto, S.; Yoshinaga, J.; Tohyama, C. Prenatal zinc deficiency-dependent epigenetic alterations of mouse metallothionein-2 gene. J. Nutr. Biochem. 2013, 24, 256-266. [CrossRef]

26. Kimura, T.; Hosaka, T.; Nakanishi, T.; Aozasa, O. Long-term cadmium exposure enhances metallothionein-1 induction after subsequent exposure to high concentrations of cadmium in P1798 mouse lymphosarcoma cells. J. Toxicol. Sci. 2019, 44, 309-316. [CrossRef]

27. de Andres, M.C.; Imagawa, K.; Hashimoto, K.; Gonzalez, A.; Roach, H.I.; Goldring, M.B.; Oreffo, R.O. Loss of methylation in CpG sites in the NF-kappaB enhancer elements of inducible nitric oxide synthase is responsible for gene induction in human articular chondrocytes. Arthritis Rheum. 2013, 65, 732-742. [CrossRef]

28. Ling, L.; Ren, M.; Yang, C.; Lao, G.; Chen, L.; Luo, H.; Feng, Z.; Yan, L. Role of site-specific DNA demethylation in TNFalpha-induced MMP9 expression in keratinocytes. J. Mol. Endocrinol. 2013, 50, 279-290. [CrossRef]

29. Han, W.; Shi, M.; Spivack, S.D. Site-specific methylated reporter constructs for functional analysis of DNA methylation. Epigenetics 2013, 8, 1176-1187. [CrossRef]

30. Urbano, A.; Smith, J.; Weeks, R.J.; Chatterjee, A. Gene-Specific Targeting of DNA Methylation in the Mammalian Genome. Cancers 2019, 11, 1515. [CrossRef]

31. Strober, W. Trypan Blue Exclusion Test of Cell Viability. Curr. Protoc. Immunol. 2015, 111, A3.B.1-A3.B.3. [CrossRef] [PubMed]

32. Henning, A.L.; Sampson, J.N.B.; McFarlin, B.K. Measurement of Low-Abundance Intracellular mRNA Using Amplified FISH Staining and Image-Based Flow Cytometry. Curr. Protoc. Cytom. 2016, 76. [CrossRef] [PubMed]

33. Kumaki, Y.; Oda, M.; Okano, M. QUMA: Quantification tool for methylation analysis. Nucleic Acids Res. 2008, 36, W170-W175. [CrossRef] [PubMed]

(C) 2020 by the authors. Licensee MDPI, Basel, Switzerland. This article is an open access article distributed under the terms and conditions of the Creative Commons Attribution (CC BY) license (http://creativecommons.org/licenses/by/4.0/). 